\title{
Meningocele manqué
}

\author{
Annelise Aquilina, ${ }^{1}$ Gabriel Galea, ${ }^{2}$ Reuben Grech ${ }^{3}$
}

${ }^{1}$ Mater Dei Hospital, Attard, Malta

${ }^{2}$ Medical Imaging Department, Mater Dei Hospital, Msida, Malta

${ }^{3}$ Mater Dei Hospital, Msida, Malta

\section{Correspondence to} Dr Annelise Aquilina, annie.aquilina@gmail.com

Accepted 14 April 2017

\section{DESCRIPTION}

A 53-year-old man presented with right-sided sciatic-like pain. He was otherwise asymptomatic with no weakness, sphincter disturbances or gait problems. On examination, upper motor neuron signs were elicited in both lower limbs and an MRI of the whole spine was requested.

MRI showed dorsal tethering of the spinal cord secondary to a fibrous band, associated with two midline lipomas (figure 1). The affected cord segment was triangular in cross section (figure 2), and a syrinx was also observed at the affected level. Radiological appearances were compatible with meningocele manqué (MM).

Spinal dysraphism is a broad term which refers to a variety of developmental anomalies occurring in the dorsum of the embryo resulting from abnormal fusion of midline structures. ${ }^{1}$

Tethered spinal cord syndrome is a type of spinal dysraphism caused by abnormal tissue bands which limit movement of the spinal cord within the spinal column. ${ }^{2}$ It may be congenital in origin or acquired due to mechanical trauma aggravated by repeated flexion and extension movements or the development of fibrosis in genetically predisposed individuals.

MM has been described as a type of tethered spinal cord caused by fibrous bands or atretic neural tissue to dura or other surrounding structures. It has been diagnosed in neonates; however, it is more commonly found incidentally during investigations for other elements of spinal dysraphism. MRI is considered as the

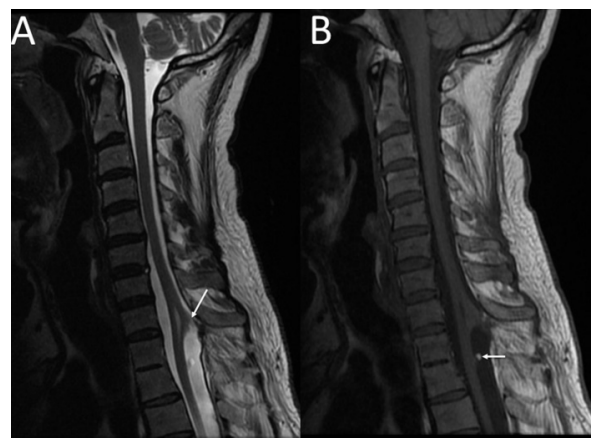

Figure 1 Sagittal T2-weighted (A) and T1-weighted CrossMark

To cite: Aquilina A, Galea $\mathrm{G}$, Grech R. BMJ Case Rep Published Online First: [please include Day Month Year]. doi:10.1136/bcr-2017 220213
(B) MRI of the cervical spine shows a thin band of tissue tethering the dorsal cord to the dura at T1-2 level (arrow) with resultant formation of a syrinx. At T2-3 level, there is a focal lesion at the dorsal aspect of the thoracic cord with high signal at its tip in keeping with a lipoma of the cord (better appreciated on T1-weighted images-arrow, B). T2-3 vertebrae are also fused in keeping with block vertebrae.

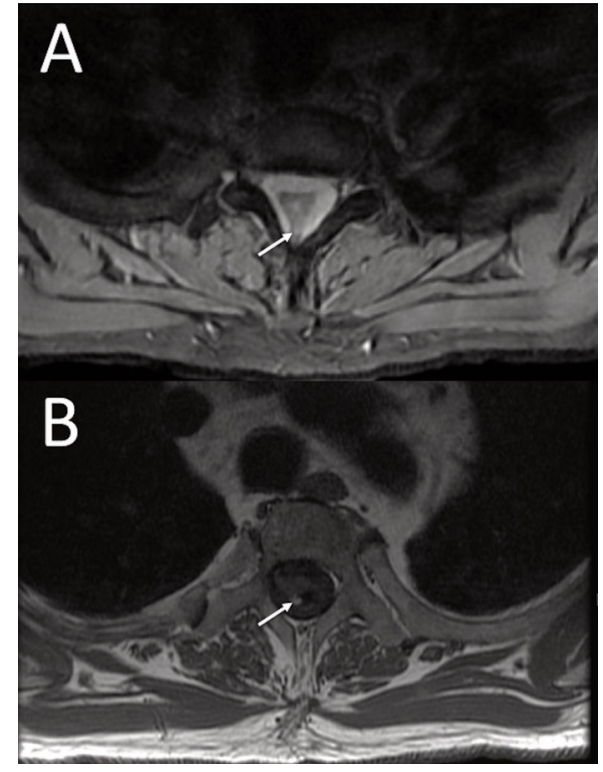

Figure 2 Axial T2-weighted (A) and T1-weighted (B) MRI at T1-2 level again demonstrates the band of tissue (arrow, A) extending posteriorly from the dorsal aspect of the spinal cord to the dura in keeping with a meningocoele manqué. Focal dilatation of the central canal of the cord is again noted. The thoracic cord at this level is triangular in cross section. Note is again made of an associated lipoma (arrow, B).

'gold-standard' imaging technique in spinal dysraphisms.

In our case, the patient was offered corrective surgery; however, he refused and opted for conservative management.

\section{Learning points}

- Radiological findings of meningocele manqué include fibrous bands causing dorsal tethering of the spinal cord. Associated findings may include lipomas and syrinx formation.

- The diagnosis of tethered cord syndrome in adulthood is an unusual but well-described entity. ${ }^{2}$ The delay in presentation may be associated with the accumulation of microtrauma caused by repetitive spinal flexion and extension.

- Surgical intervention may be offered to all symptomatic patients and to asymptomatic patients who lead physically active lives. ${ }^{2}$

Contributors The MRIs were seen and reported by GG and by RG AA came across the images while completing her radiology rotation under the supervision of $\mathrm{RG}$ and $\mathrm{GG}$.

Competing interests None declared. 


\section{Images in...}

\section{Patient consent Obtained.}

Provenance and peer review Not commissioned; externally peer reviewed.

(c) BMJ Publishing Group Ltd (unless otherwise stated in the text of the article) 2017. All rights reserved. No commercial use is permitted unless otherwise expressly granted.

\section{REFERENCES}

1 Radiopedia.org [Internet]. Tethered cord. https://radiopaedia.org/articles/spinaldysraphism (accessed 18 Feb 2017).

2 Warder DE. Tethered cord syndrome and occult spinal dysraphism. Neurosurg Focus 2001;10:1-9.

3 Kaffenberger DA, Heinz ER, Oakes JW, et al. Meningocele Manque: radiological findings with clinical correlation. AJNR Am J Neuroradiol 1992;13:1083-8.

Copyright 2017 BMJ Publishing Group. All rights reserved. For permission to reuse any of this content visit http://group.bmj.com/group/rights-licensing/permissions.

BMJ Case Report Fellows may re-use this article for personal use and teaching without any further permission.

Become a Fellow of BMJ Case Reports today and you can:

- Submit as many cases as you like

Enjoy fast sympathetic peer review and rapid publication of accepted articles

- Access all the published articles

- Re-use any of the published material for personal use and teaching without further permission

For information on Institutional Fellowships contact consortiasales@bmjgroup.com

Visit casereports.bmj.com for more articles like this and to become a Fellow 